\title{
Partitioning of potentially toxic elements among two colloidal fractions and relevance for their mobility in different water types
}

\author{
Filipa Moreno ${ }^{1}$, Teresa Valente $^{1, *}$, Patrícia Gomes $^{1}$, Rita Fonseca $^{2}$, Maria Rosário Costa ${ }^{3}$, \\ and Ana Costa $^{1}$ \\ ${ }^{1} \mathrm{ICT}$, Institute of Earth Sciences, Pole of the University of Minho, Earth Sciences Department, \\ Campus de Gualtar, 4710 Braga, Portugal \\ ${ }^{2} \mathrm{ICT}$, Institute of Earth Sciences, Pole of the University of Évora, Department of Geosciences, School \\ of Sciences and Technology, University of Évora, 94, Évora, Portugal \\ ${ }^{3}$ Departamento de Geologia, UTAD, Vila Real; GeoBioTec, Universidade de Aveiro, Portugal
}

\begin{abstract}
Potentially toxic elements are mobilized in aquatic systems in solution or bounded to colloids of different sizes, which may include nanometer particles. The present work studies the distribution of elements (Al, Fe, $\mathrm{Zn}, \mathrm{Mn}, \mathrm{Co}, \mathrm{Cd}, \mathrm{Ni}, \mathrm{Cu}$, and As) between small $(<0.20 \mu \mathrm{m})$ and larger $(0.45-0.20 \mu \mathrm{m})$ colloids in different waters sources in a world class metallogenic province (Iberian Pyrite Belt), including the acid mine waters. Syringe filters with pore-size ratings of $0.20 \mu \mathrm{m}$ and $0.45 \mu \mathrm{m}$ have been used to assess the transport and fate of these potentially toxic elements. The results show the contribution of colloids for mobility of arsenic and most metals, evidencing the role of the small ones in acid mine drainage.
\end{abstract}

\section{Introduction}

The presence of significant colloidal metal(loid) fractions in water bodies has implications on the transport, fate and bioavailability of potentially toxic elements (PTE). Although transported as efficiently as the dissolved metal(loid)s, they cannot be subject to some of the mechanisms that affect the truly dissolved [1]. Besides, PTE bound to colloids may harmfully affect riverine habitats and biota [2]. Also, it was found that colloids may serve as a critical intermediary from solution to particulate $(>0.45 \mu \mathrm{m})$ phases, playing important roles in a series of interface interactions [1]. Therefore, the straight practice of (operationally) distinguishing between particulate and dissolved phases, using membrane or filters with $0.45 \mu \mathrm{m}$ pore-size may greatly neglect the importance of colloids $[3,4,5]$. This likewise drew attention to the inadequacy of this cut-off on the comprehensive understanding of the behaviour (and effects) of the heterogeneous and multisource material found in natural systems. This scenario attains utmost expression in systems impacted by acid mine drainage (AMD), where the formation of iron ultrafine colloids in the nanoscale

\footnotetext{
* Corresponding author: teresav@dct.uminho.pt
} 
size, rapidly evolving and dictating many biogeochemical processes, is ubiquitous. Such framework may compromise the acquisition of reliable results and accurate predictions on the PTE behaviour throughout the impacted water bodies [6].

This work aimed to compare the application of two $(0.45$ and $0.20 \mu \mathrm{m})$ pore-size syringe filters in the treatment of different waters types from the Iberian Pyrite Belt (IPB), seeking meaningful relationships with regard to the PTE partitioning among both fractions.

\section{Study area}

The IPB is a Variscan metallogenic province in southwestern Portugal and Spain. It comprises around 90 volcanogenic massive sulphide (VHMS) deposits exploited long before Roman times (4000 BC).

In the Portuguese part of the belt there are two supergiant (Neves Corvo and Aljustrel) and two world-class (Lousal and S. Domingos) VHMS deposits (Fig.1), whose exploitation ceased in the 1960s. Such a context has made from the IPB a worldwide case of environmental impact triggered by intensive and long-lasting mining works, risking water resources quality on a regional scale. Additionally, the generation of acid waters by the erosion of sulphides enhanced the possibility of natural contamination.

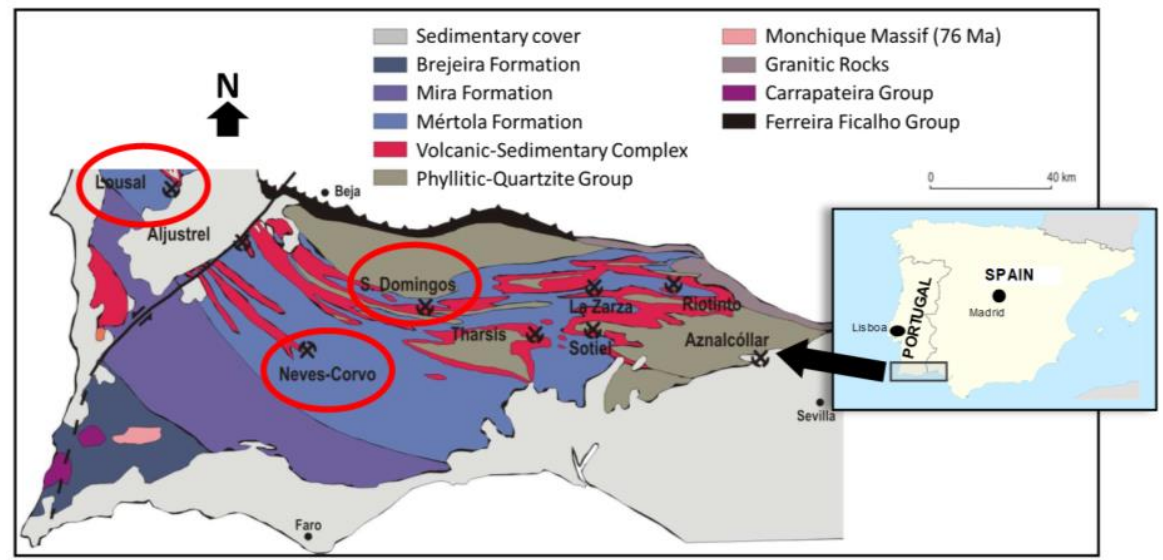

Fig. 1. Simplified geological map of the Iberian Pyrite Belt, with the location of some of the main massive sulphide deposits both in Portugal and Spain (adapted from [7]).

\section{Experimental section}

Surface and groundwater samples were collected in $1 \mathrm{~L}$ polypropylene bottles at twelve sampling sites from the Portuguese sector of the IPB, in the Caveira, Lousal-Aljustrel, Neves Corvo and S. Domingos surrounding areas (Fig. 1). Two aliquots of $100 \mathrm{~mL}$ were filtered in the field using syringe-filters at 0.45 and $0.20 \mu \mathrm{m}$, acidified to $\mathrm{pH}<2$ and stored in the dark at $4^{\circ} \mathrm{C}$ up to chemical analysis.

At each sampling site, the parameters $\mathrm{pH}$, temperature, electrical conductivity (EC) and redox potential were also measured. Metals ( $\mathrm{Al}, \mathrm{Fe}, \mathrm{Cd}, \mathrm{Co}, \mathrm{Cu}, \mathrm{Mn}, \mathrm{Ni}, \mathrm{Pb}$, and $\mathrm{Zn}$ ) and arsenic (As) analyses were carried out by inductively coupled plasma optical emission spectroscopy. Blanks, replicates and stock solutions were used to assess quality control. 


\section{Results and discussion}

Table 1 shows the main characteristics of the surface and groundwater sampling sites along with the field parameters.

Table 1. Main characteristics of the sampling sites and in situ parameters. EC-Electrical Conductivity.

\begin{tabular}{|l|l|l|l|c|c|c|c|}
\hline $\begin{array}{c}\text { Sampling } \\
\text { Site }\end{array}$ & \multicolumn{2}{|c|}{ GPS Coordinates } & \multicolumn{1}{|c|}{ Water type } & pH & $\begin{array}{c}\text { Temp. } \\
\left({ }^{\circ} \mathbf{C}\right)\end{array}$ & $\begin{array}{c}\text { EC } \\
(\mu \mathbf{\mu} / \mathbf{c m})\end{array}$ & $\begin{array}{c}\text { Redox } \\
(\mathbf{m V})\end{array}$ \\
\hline CR4 & $38.129854 \mathrm{~N}$ & $8.489020 \mathrm{~W}$ & River & 7,19 & 9,5 & 807 & 301 \\
\hline NCR3 & $37.572618 \mathrm{~N}$ & $7.922868 \mathrm{~W}$ & River & 7,71 & 14,9 & 2480 & 253 \\
\hline CR3 & $38.129706 \mathrm{~N}$ & $8.488967 \mathrm{~W}$ & AMD-stream & 2,13 & 10,6 & 7670 & 568 \\
\hline SDB6 & $37.659443 \mathrm{~N}$ & $7.505498 \mathrm{~W}$ & Mining dam-AMD & 3,06 & 14,6 & 4670 & 557 \\
\hline SDX & $37.624839 \mathrm{~N}$ & $7.514642 \mathrm{~W}$ & AMD-stream & 3,47 & 15,3 & 2500 & 419 \\
\hline ALB2 & $37.936321 \mathrm{~N}$ & $8.078221 \mathrm{~W}$ & Water reservoir & 8,27 & 14,5 & 629 & 159 \\
\hline SD A & $37.669681 \mathrm{~N}$ & $7.504839 \mathrm{~W}$ & Water reservoir & 8,57 & 14,1 & 300 & 340 \\
\hline CE1 & $38.120180 \mathrm{~N}$ & $8.498567 \mathrm{~W}$ & AMD-stream & 1,80 & 11,9 & 19500 & 513 \\
\hline SDE5 & $37.665221 \mathrm{~N}$ & $7.502691 \mathrm{~W}$ & Mining dam-AMD & 2,71 & 18,5 & 2830 & 510 \\
\hline SDC4 & $37.669397 \mathrm{~N}$ & $7.493563 \mathrm{~W}$ & Pit lake-AMD & 2,67 & 13,1 & 8460 & 539 \\
\hline NCF1 & $37.572296 \mathrm{~N}$ & $7.915187 \mathrm{~W}$ & Groundwater & 7,42 & 15,4 & 1400 & 243 \\
\hline SDF9 & $37.702010 \mathrm{~N}$ & $7.479217 \mathrm{~W}$ & Groundwater & 7,73 & 20,1 & 1680 & 354 \\
\hline
\end{tabular}

The waters have a $\mathrm{pH}$ range of 1.80 (CE1, in the AMD stream in the Caveira, AljustrelLousal sector) to 8.57 (SD A water reservoir in the S. Domingos area). These two samples have also the maximum $(19500 \mu \mathrm{m} / \mathrm{cm})$ and minimum $(300 \mu \mathrm{m} / \mathrm{cm}) \mathrm{ECs}$, the first expressing the leaching of the Caveira mine sulphide wastes, as already reported by [8]. Like $\mathrm{pH}$, the filtered metal contents $(<0.45$ and $<0.20 \mu \mathrm{m})$ at the several sampling locations are very distinct, reflecting the heterogeneity of the waters. This can be seen in Table 2, which presents the main statistics of the analysed PTE in the two-filtered fractions.

Table 2. Metals and As contents in the two-filtered fractions ( $<0.45 \mu \mathrm{m}$ and $<0.20 \mu \mathrm{m}$ fractions).

\begin{tabular}{|c|c|c|c|c|c|c|c|c|c|c|}
\hline $\begin{array}{c}\text { Water samples } \\
(<0.45 \mu \mathrm{m})\end{array}$ & $\begin{array}{c}\mathrm{Al} \\
(\mathrm{mg} / \mathrm{L}) \\
(\mathrm{N}=12) \\
\end{array}$ & $\begin{array}{c}\mathrm{Fe} \\
(\mathrm{mg} / \mathrm{L}) \\
(\mathrm{N}=12)\end{array}$ & $\begin{array}{c}\text { As } \\
(\mathrm{mg} / \mathrm{L}) \\
(\mathrm{N}=12)\end{array}$ & $\begin{array}{c}\mathrm{Cd} \\
(\mathrm{mg} / \mathrm{L}) \\
(\mathrm{N}=6)\end{array}$ & $\begin{array}{c}\text { Co } \\
(\mathrm{mg} / \mathrm{L}) \\
(\mathrm{N}=7)\end{array}$ & $\begin{array}{c}\mathrm{Cu} \\
(\mathrm{mg} / \mathrm{L}) \\
(\mathrm{N}=12) \\
\end{array}$ & $\begin{array}{c}\mathrm{Mn} \\
(\mathrm{mg} / \mathrm{L}) \\
(\mathrm{N}=9)\end{array}$ & $\begin{array}{c}\mathrm{Ni} \\
(\mathrm{mg} / \mathrm{L}) \\
(\mathrm{N}=10)\end{array}$ & $\begin{array}{c}\mathrm{Pb} \\
(\mathrm{mg} / \mathrm{L}) \\
(\mathrm{N}=6)\end{array}$ & $\begin{array}{c}\mathrm{Zn} \\
(\mathrm{mg} / \mathrm{L}) \\
(\mathrm{N}=12)\end{array}$ \\
\hline Minimum & 0.25 & 0.03 & 0.05 & $<0.005$ & 0.01 & 0.02 & $<0.005$ & $<0.005$ & $<0.005$ & 0.02 \\
\hline Maximum & 295 & 4840 & 16.9 & 1.00 & 3.60 & 75.4 & 146 & 1.92 & 2.60 & 151 \\
\hline Mean & 102 & 711 & 1.99 & 0.43 & 1.20 & 14.0 & 29.6 & 0.49 & 0.70 & 34.3 \\
\hline Median & 39.7 & 2.15 & 0.17 & 0.26 & 0.65 & 3.65 & 7.86 & 0.18 & 0.19 & 2.97 \\
\hline $\begin{array}{c}\text { Water samples } \\
\quad(<0.20 \mu \mathrm{m})\end{array}$ & $\begin{array}{c}\mathrm{Al} \\
(\mathrm{mg} / \mathrm{L}) \\
(\mathrm{N}=12) \\
\end{array}$ & $\begin{array}{c}\mathrm{Fe} \\
(\mathrm{mg} / \mathrm{L}) \\
(\mathrm{N}=12)\end{array}$ & $\begin{array}{c}\text { As } \\
(\mathrm{mg} / \mathrm{L}) \\
(\mathrm{N}=4)\end{array}$ & $\begin{array}{c}\mathrm{Cd} \\
(\mathrm{mg} / \mathrm{L}) \\
(\mathrm{N}=12) \\
\end{array}$ & $\begin{array}{c}\mathrm{Co} \\
(\mathrm{mg} / \mathrm{L}) \\
(\mathrm{N}=11) \\
\end{array}$ & $\begin{array}{c}\mathrm{Cu} \\
(\mathrm{mg} / \mathrm{L}) \\
(\mathrm{N}=8) \\
\end{array}$ & $\begin{array}{c}\text { Mn } \\
(\mathrm{mg} / \mathrm{L}) \\
(\mathrm{N}=9) \\
\end{array}$ & $\begin{array}{c}\mathrm{Ni} \\
(\mathrm{mg} / \mathrm{L}) \\
(\mathrm{N}=7)\end{array}$ & $\begin{array}{c}\mathrm{Pb} \\
(\mathrm{mg} / \mathrm{L}) \\
(\mathrm{N}=5)\end{array}$ & $\begin{array}{c}\mathrm{Zn} \\
(\mathrm{mg} / \mathrm{L}) \\
(\mathrm{N}=12) \\
\end{array}$ \\
\hline Minimum & 0.14 & 0.01 & $<0.01$ & 0.01 & $<0.005$ & $<0.005$ & $<0.005$ & $<0.005$ & $<0.005$ & 0.04 \\
\hline Maximum & 327 & 3123 & 19.9 & 0.85 & 2.87 & 78.5 & 125 & 1.67 & 2.36 & 168 \\
\hline Mean & 105 & 420 & 6.25 & 0.20 & 0.64 & 20.3 & 25.6 & 0.58 & 0.76 & 36.7 \\
\hline Median & 39.8 & 1.60 & 2.26 & 0.04 & 0.34 & 8.45 & 6.16 & 0.44 & 0.28 & 2.34 \\
\hline
\end{tabular}

The metal contents in both fractions correspond to the cluster of samples impacted by AMD, as expected, and are several orders of magnitude higher than the remaining ones, strongly skewing PTE distributions, namely of the most abundant metals, Fe, Al, Zn, Mn and $\mathrm{Cu}$. In fact, the first three $(\mathrm{Fe}, \mathrm{Al}, \mathrm{Zn})$ are the only ones with consistently quantified values in the two-filtered fractions at all sites, while the others present negligible $(<0.005$ $\mathrm{mg} / \mathrm{L}$; or $<0.01 \mathrm{mg} / \mathrm{L}$ for As) values in some number of samples (Table 2). Altogether, the data indicate a general decrease of the colloidal metal load by using the $0.20 \mu \mathrm{m}$ pore-size. Such outcome suggests the presence of metals bonded to larger $(0.45-0.20 \mu \mathrm{m})$ colloids, thus overestimating the PTE pool of the traditionally "dissolved" fraction. 
To assess the PTE partitioning between the two-filtered fractions, the results for each of them are displayed, in Figure 2, on graphs of $<0.20 \mu \mathrm{m} v s$. $<0.45 \mu \mathrm{m}$, for the samples with measurable values in both. The line superimposed to diagrams corresponds to a $<0.20$ $\mu \mathrm{m}: 0.45 \mu \mathrm{m}$ ratio of $1: 1$, with analyses plot along this line showing no (relevant) differences between the two-filtered fractions, like reported by [9].
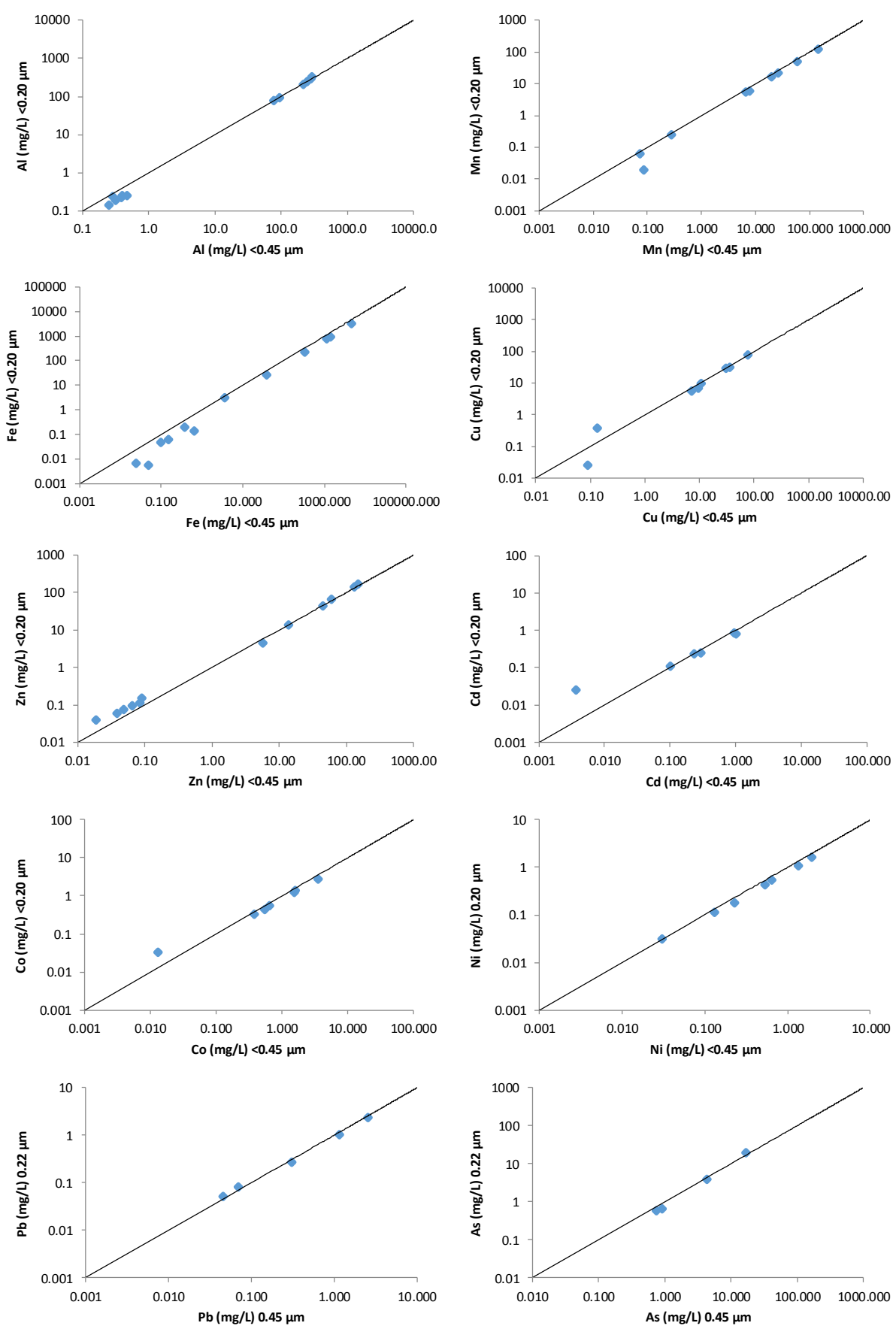

Fig. 2. PTE partitioning between the $<0.20 \mu \mathrm{m}$ and the $0.45 \mu \mathrm{m}$ fractions. 
As can be seen, relationships roughly equal or lower than 1 prevail for As and all metals but $\mathrm{Zn}$. The $(\sim 1: 1)$ ratio suggests that PTE are tied up in $<0.20 \mu \mathrm{m}$ colloids or as dissolved elements. Some samples show slightly lower ratio for elements such as $\mathrm{Al}, \mathrm{Fe}$ and $\mathrm{Mn}$. This seems to indicate the role of the larger $(0.45-0.20 \mu \mathrm{m})$ colloidal phases in retaining those elements, which happens for the least mineralized waters. This might occur in relation with $\mathrm{pH}$, with alkaline waters transporting typically higher suspended load than highly acidic ones [10].

The comparison between the $0.45 \mu \mathrm{m}$ and $0.20 \mu \mathrm{m}$ filtrates from waters with different hydrochemical features allowed to confirm the occurrence of PTE associated to colloids within the $<0.20 \mu \mathrm{m}$ size, and thus better constrain the truly dissolved fraction particularly in AMD-affected samples. Here natural colloids, some of them as nanoparticles $(<100 \mathrm{~nm})$, are formed by a variety of materials holding a diversity of complexation sites that retain PTE. In aquatic systems as the ones affected by AMD, the retention is assumed to be made mostly on newly formed Fe-rich colloids, such as schwertmannite, low crystalline hydrous ferric oxides and a variety of amorphous materials.

The colloids such as nanoparticles may contribute to increase the potential for mobilizing PTE to greater distances, and misleading its chemical behaviour, namely reaction affinities, kinetics and bioavailability [11].

This work was co-funded by the European Union through the European Regional Development Fund, based on COMPETE 2020 - project ICT (UID/GEO/04683/2013) with reference POCI-01-0145FEDER-007690 and project Nano-MINENV number 029259. Patrícia Gomes wishes to acknowledge FCT by the research fellowship under the POCH supported by the European Social Fund and National Funds of MCTES with reference SFRH/BD/108887/2015.

\section{References}

1. J.M. Ross, R.M. Sherrell, Limnol. Oceanogr. 44, 1019 (1999)

2. L.E. Schemel, Briant A., Kimball, K. E. Bencala, Appl. Geochem. 15, 1003 (2000)

3. A J. Horowitz, K.A. Elrick, M.R. Colberg, Water Res., 26, 753 (1992)

4. M. Gardner, S. Comber, Analyst 122, 1029 (1997)

5. M. Morrison, G. Benoit, Environ. Sci. Technol. 35, 3774 (2001)

6. T. Valente, L. Guise, C.A. Leal Gomes, Geochem-Explor. Env. A 11, 71 (2011)

7. T. Oliveira, J.M.R.S. Relvas, Z. Pereira, J.X. Matos, C.J. Rosa, D. Rosa, J.M. Munhá, R.C.G.S. Jorge, A.M.M. Pinto, In: Geologia de Portugal no Contexto da Ibéria (Univ. Évora, Évora, Portugal, 2006)

8. E. Ferreira da Silva, N. Durães, P. Reis, C. Patinha, J. Matos, M.R. Costa, J. Geochem. Explor. 159, 33 (2015)

9. C.H. Gammons, T.P. Mulholland, A.K. Frandsen, Mine Water and the Environ. 19, $111(2000)$

10. G. Pan, P.S. Liss, M.D. Krom, Colloids and Surfaces A: Physicochemical and Engineering Aspects 151, 127 (1999)

11. M.F. Hochella Jr., Elements, 4, 373 (2008) 